\title{
Leveraging Web Technologies for Collaborative Problem-Solving in an Authentic Learning Environment
}

\author{
Heidi Tan Yeen-Ju and Neo Mai
}

\begin{abstract}
This paper presents a study that sought to look at the use of web technologies in supporting collaboration among undergraduate students working in groups to solve problems. The learning environment was designed to be authentic, centering on a problem-based group project and incorporated web technologies. Student attitude and perceptions were gathered through the use of a 5-point Likert scale questionnaire, open ended questions and interviews. The results indicate that students responded positively towards this learning environment and support the incorporation of web technologies to create conducive learning environments that facilitate collaborative problem-solving.
\end{abstract}

Index Terms-Authentic learning environments, problem-solving, web technologies.

\section{INTRODUCTION}

Educators are increasingly being encouraged to incorporate web technologies into their teaching and learning strategies. The emergence of Web 2.0 tools has shifted the way users participate online, moving from passive consumers of content to active content generators [1] and while Web 2.0 is nothing new, in recent years there has been an increase in interest towards Web 2.0 tools for education purposes [2]. Educators are now looking at ways to engage the current generation of learners who are also often known as "digital natives" and are said to think and process information differently due to being surrounded by technology from a young age [3]. Research has found that students in Malaysia currently go through an education system that ill-prepares them for the working world as these graduates have been found to lack problem-solving skills and communication skills [4]. There are recommendations for the focus to be placed on designing learning environments that center on problem-solving [5] and authentic learning which exposes students to the complexities of the real working world [6]. This has spurred the Malaysian Ministry of Higher Education to focus on encouraging higher education institutions to implement teaching and learning strategies that incorporates Information Communication Technology (ICT) to help increase graduate employability [7], [8]. Therefore, this study was conducted with the intention to answer this research question: Can web technologies support collaborative problem-solving among students?

Manuscript received November 25, 2014; revised March 5, 2015. This project was funded under the TM R\&D grant.

The authors are with the Faculty of Creative Multimedia, Multimedia University, Cyberjaya, Malaysia (e-mail: yjtan@mmu.edu.my, neo.mai@mmu.edu.my).

\section{WeB TECHNOLOGY AS ENABLERS FOR COLlABORATIVE LEARNING IN AN AUTHENTIC LEARNING ENVIRONMENT}

Web technology or web tools can become enablers for collaborative learning when embedded into a learning environment as research has shown that these web technologies are important tools for learning and discovery [9]. In the mapping of technologies against communication and interaction, blogs and social networking sites emerge as Web 2.0 tools that are shown to support both communication with others and interaction with resources and other tools [1]. Web 2.0 tools places emphasis on participation of the users and the content are generated by the users themselves [10] therefore potentially being able to encourage collaboration amongst students when used in an education setting [11]. Reference [1] however cautions that while these web tools are able to support communication and interaction, the method in which they are used will determine the degree of communication and interaction supported by the tool.

Collaborative learning is defined by [12], [13] as a learning situation in which a group of students work together to achieve a common goal, completing the task together through communication and a joint solution to solve the task. Research has found that learners often found collaborative group work enjoyable and gave them a better learning experience. Working collaboratively was also found to expose learners to a wider array of perspectives, allowing them to do better in their learning outcomes [14]. Web technology has been noted to be advantageous towards creating learning environments that are collaborative and interactive [15]. While technology has the advantage of allowing an easier shift in the roles of learners and educators [16], its advantages can only be realized through the careful design of learning environments with sound theoretical frameworks. Therefore in this study, the learning environment was designed with the adaptation of 9 theoretically based authentic learning principles outlined by [17] as authentic learning and web technology have been shown to be mutually beneficial when implemented together [18].

\section{THE STUDY}

The aim of this study was to look at the use of web technologies in an authentic learning environment and its effects on fostering collaborative problem-solving among students. The students who volunteered to participate in this study were undergraduate students from Multimedia University Cyberjaya's management faculty. A total of 29 students with minimal to no experience in multimedia content creation were undertaking a Multimedia-related core 
subject at the Faculty of Creative Multimedia. The intended learning outcomes of the subject was to for the management students to understand basic multimedia principles and to create multimedia content for the web. The class consisted of both local and international students (Malaysia, Indonesia, Nigeria, Brunei, Saudi, China, and Bangladesh) from diverse ethnic backgrounds with 18 male students and 11 female students from the age of 21 to 26 .

The subject was conducted for one trimester (14 study weeks) in which students were required to form groups of 4 to 5 and work collaboratively to solve a problem-based group project. The learning environment was designed to incorporate web technologies into the existing face-to-face learning that occurs in a physical classroom and therefore had an online component as part of the learning environment. Within the face-to-face learning component of this blended learning environment, students would attend lectures and have in-class discussions on various related topics as well as consultations with the lecturer. In the online learning environment, students would access interactive multimedia modules to learn fundamental knowledge on multimedia, document their learning process on their blogs and have discussions via social media sites like Facebook. The entire blended learning environment was designed and built by adapting 9 theoretically based authentic learning principles as outlined by [17]. These 9 authentic learning principles are: Authentic Context, Authentic Activities, Expert Performance, Multiple Roles and Perspectives, Collaboration, Reflection, Articulation, Coaching and Scaffolding, and Integrated Authentic Assessment. The details of their implementation in this learning environment will be explained in the following section as part of the collaborative problem-solving process.

\section{The Collaborative Problem-Solving Process SuPPORTED By Web TECHNOLOGIES}

Fig. 1 illustrates an example of the student learning process throughout the duration of the project. It also represents the collaborative problem-solving process students went through in trying to complete the group project. Screenshots provided in Fig. 1 is an example of one group's learning process from the point they were given the problem-based group project to solve until the final project outcome. The process was designed to be as authentic as possible through the adaptation of 9 authentic learning principles by [17]. The seamless implementation of the authentic learning principles is elaborated below:

\section{A. Students Were Presented with an Authentic Task to Solve}

An authentic learning environment should be designed with authentic context that reflect how knowledge will eventually be used in the real world. Therefore this learning environment was designed to simulate as closely as possible a real-world scenario in which students may face in the working world. Learning content provided in the form of lecture notes and interactive multimedia modules were based on class curriculum and contained vital information that would facilitate the completion of the project. Students were presented with an authentic task in the form of a problem-based group project which was to redesign an existing website. The project would allow students to understand how the theoretical knowledge they learn can be applied in real life situations.

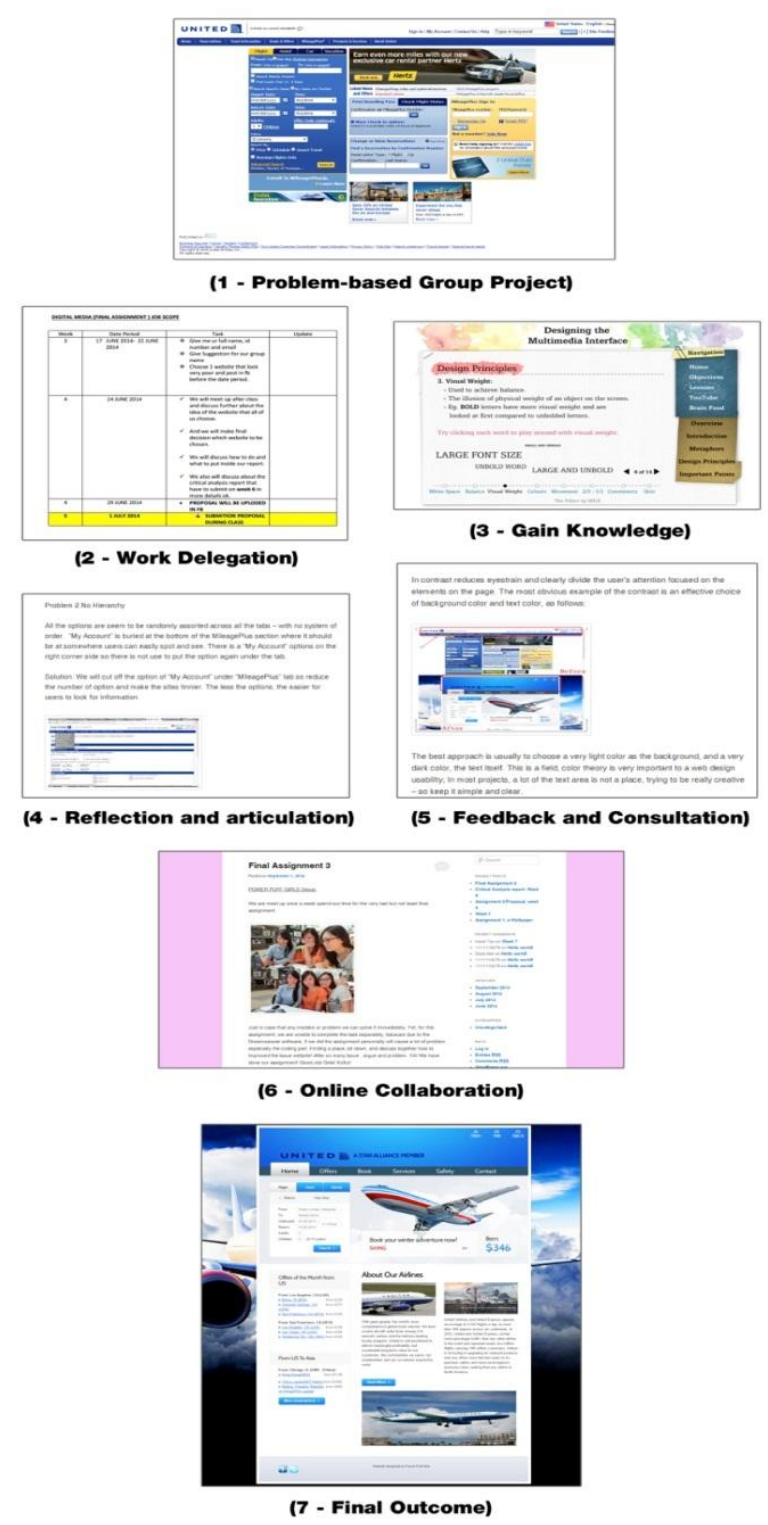

Fig. 1. The student learning process.

\section{B. Division of Roles and Responsibilities}

Students had to divide and delegate the tasks they needed to accomplish for the project, turning them into decision makers who had to be responsible for various roles throughout the duration of the project. Students had to apply their project management skills and plan their time well. In class, students were required to submit a detailed report and proposal on their plans to redesign any website of their choice.

\section{Exposure to Multiple Viewpoints on a Topic}

An authentic learning environment provides a learning environment that allows students to see a topic from various points of view. Therefore in this learning environment, students were able to learn fundamentals of multimedia via media-rich interactive modules made available to them 24/7. Students were also encouraged to fully utilize the web tools available in the online learning environment to do their 
research and look for resources to help them solve their project. Students were able to refer to the learning materials at all times to facilitate them in completing the project.

\section{Reflection and Articulation}

An authentic learning environment allows for students to reflect on knowledge obtained and to have opportunities for speaking out or sharing their ideas with their peers. In this learning environment, blogs provided students with a public platform to document what they have learnt and to also share their ideas. Throughout the process of completing the project, students used their blogs to document everything they learnt and they showed how they applied the knowledge gained towards solving their group project.

\section{E. Feedback and Consultations}

In an authentic learning environment, the lecturer is given the role of facilitator and provides coaching or scaffolding when necessary. Students should also be given access to expert performances before they attempt a task. In this learning environment, not only do students get scaffold during face-to-face consultations with their lecturer, they also receive feedback and comments from their lecturer and peers online via the blogs and social media tools. The tutors serve as experts who show students how to use authoring tools before the students attempt it on their own and students were also encouraged to watch videos of experts online and learn from them.

\section{F. Online Collaboration}

An authentic learning environment ensures students are able to work together and have social support. In this learning environment, the group project fostered collaborative efforts be it online or offline. Students worked together in class to solve the problem-based project and seamlessly continued this out of the class through the use of blogs and social media tools like Facebook.

\section{G. Final Outcome and Assessment}

Authentic learning environments encourage the use of integrated authentic assessments to measure a student's learning outcome. In this learning environment, students were assessed at various stages throughout the project until the final outcome was presented and submitted.

\section{RESUlTS AND DisCUSSIONS}

This study was conducted using a mixed method mode of research in which both quantitative and qualitative instruments were used to measure student's attitudes and perceptions towards the use of web technologies in an authentic learning environment. Data was collected via a 5-point Likert scale questionnaire, open ended questions and interviews. The 5-point Likert scale questionnaire contained 20 survey items and 5 open ended questions. The survey was conducted at the end of the trimester after students presented their final project outcome. Table I presents the result of the survey and is broken down into mean (M), standard deviation (SD), and percentage (P). Overall the survey items yielded a Cronbach's Alpha of 0.931 which according to [19] can be considered as reliable.

TABLE I: LEARNING ENVIRONMENT SURVEY (DESCENDING ORDER)

\begin{tabular}{|c|c|c|c|c|}
\hline No & Survey Items & $\begin{array}{l}\text { Mean } \\
(\mathrm{M})\end{array}$ & $\begin{array}{l}\text { Std. } \\
\text { Deviation } \\
\text { (SD) }\end{array}$ & $\begin{array}{l}\% \\
(P)\end{array}$ \\
\hline 1 & $\begin{array}{l}\text { Liked use multimedia to explain } \\
\text { a topic }\end{array}$ & 4.69 & .660 & 96.6 \\
\hline 2 & $\begin{array}{l}\text { Lecturer/tutor an important } \\
\text { source of knowledge }\end{array}$ & 4.59 & .568 & 96.6 \\
\hline 3 & $\begin{array}{l}\text { Enjoyed working together with } \\
\text { classmates }\end{array}$ & 4.48 & .949 & 93.1 \\
\hline 4 & $\begin{array}{l}\text { Project allowed learning of new } \\
\text { skills and knowledge }\end{array}$ & 4.48 & .574 & 96.6 \\
\hline 5 & $\begin{array}{l}\text { Important to seek help from the } \\
\text { lecturer when facing } \\
\text { problems/issues }\end{array}$ & 4.45 & .686 & 96.6 \\
\hline 6 & $\begin{array}{l}\text { Able to solve issues when } \\
\text { working together with others }\end{array}$ & 4.45 & .736 & 93.1 \\
\hline 7 & Found online tutorials helpful & 4.38 & .622 & 93.1 \\
\hline 8 & $\begin{array}{l}\text { Found it helpful to approach } \\
\text { lecturer for advice }\end{array}$ & 4.38 & .677 & 96.6 \\
\hline 9 & $\begin{array}{l}\text { Consulting with the lecturer } \\
\text { helped }\end{array}$ & 4.34 & .857 & 82.8 \\
\hline 10 & $\begin{array}{l}\text { Knowledge gained from the } \\
\text { class is useful to me }\end{array}$ & 4.34 & .670 & 89.7 \\
\hline 11 & $\begin{array}{l}\text { Feedback from classmates was } \\
\text { helpful }\end{array}$ & 4.31 & .967 & 89.7 \\
\hline 12 & $\begin{array}{l}\text { Support from the lecturer was } \\
\text { important }\end{array}$ & 4.31 & .712 & 93.1 \\
\hline 13 & $\begin{array}{l}\text { Able to see how knowledge can } \\
\text { be used for other projects }\end{array}$ & 4.28 & .751 & 89.7 \\
\hline 14 & $\begin{array}{l}\text { Able to compare ideas with my } \\
\text { peers and lecturer }\end{array}$ & 4.28 & .649 & 89.7 \\
\hline 15 & $\begin{array}{l}\text { Project gave real-world } \\
\text { experience }\end{array}$ & 4.24 & .739 & 82.8 \\
\hline 16 & $\begin{array}{l}\text { Web was useful in collaborating } \\
\text { with peers }\end{array}$ & 4.24 & .636 & 89.7 \\
\hline 17 & $\begin{array}{l}\text { Working with others motivates } \\
\text { me to do better }\end{array}$ & 4.21 & .940 & 89.7 \\
\hline 18 & $\begin{array}{l}\text { Able to show skills and } \\
\text { knowledge through project }\end{array}$ & 4.21 & .861 & 79.3 \\
\hline 19 & $\begin{array}{l}\text { Able to better understand how } \\
\text { knowledge is used in real life }\end{array}$ & 4.21 & .559 & 93.1 \\
\hline 20 & $\begin{array}{l}\text { Web helpful in providing } \\
\text { resources and knowledge from } \\
\text { experts }\end{array}$ & 4.21 & .819 & 82.8 \\
\hline$N=$ & , Cronbach's Alpha $=0.931$ & & & \\
\hline
\end{tabular}

\section{A. Increased Motivation through Group Work}

93.1\% of students agreed that they enjoyed working together with their group members (Item\#2, M=4.48), they found that working together with their peers allowed them to better solve problems they face (Item\#6, M=4.45). Students indicated that they liked receiving feedbacks from classmates (Item\#11, M=4.31) and were able to compare their ideas with peers (Item\#14, M=4.28). Overall, $89.7 \%$ of students agreed that working with others motivated them to do better (Item\#17, M=4.21).

Student comments to support this (quoted ad verbatim): 
“...I had a lot of support from my group member to complete this project."

"They were great help, without my group member I'm unable to complete my part."

"The person who helped me during the final project was my group mates when I couldn't find a way to do something."

\section{B. Authenticity and Relevancy of Project}

Majority of the students (Item\#4, M=4.48, 96.6\%) found that the project allowed them to learn new skills and gain new knowledge. Students also agreed that this new knowledge is useful to them (Item\#10, M=4.34) and can see how it can be used for other projects (Item\#13, M=4.28). 82.8\% of students felt the project gave them real-world experience (Item\#15, $\mathrm{M}=4.24$ ) with $79.3 \%$ agreeing that they were able to show their newly learnt skills and knowledge through the project (Item\#18, M=4.21). Overall $93.1 \%$ of students agree that they now understand better how knowledge is used in real life (Item\#19, M=4.21).

Student comments to support this (quoted ad verbatim):

"The project teach me how to arrange a website. It also train and brainstorming what can I do to attract people to read and visit my website."

"It helped me a lot to think out of the box as we all need to redesign a lame website to become better."

"Things that I like about the final exam is I'm able to show my creativity how to create a fun website. I wish I can do my own website soon because I know how to deliver this knowledge that I get from Digital Media class."

\section{Enhanced Learning with Web Technology}

$93.1 \%$ of students responded positively towards watching online tutorials as they find it helpful before attempting the task (Item\#7, M=4.38). Students found the web useful in helping them collaborate with their peers (Item\#16, M=4.24). Students also agreed that the web was helpful in providing resources and knowledge from experts (Item\#20, M=4.21).

Student comments to support this (quoted ad verbatim):

"Youtube and internet sources help me a lot during my final project. The tutorial on Youtube guided me step by step to assist me in the project"

"...Internet provides a lot of information/solution that needed in project."

"It's hard but it's a fun experience. I really love to learn it again as in when I have my free time. I learned new knowledge and skills",

\section{Scaffolding Emerged as an Important Factor}

$96.6 \%$ of students preferred the lecturer to use multimedia when explaining a topic (Item\#1, M=4.69) and found that the lecturer or tutor is an important source of knowledge (Item\#2, $M=4.59$ ). Majority of the students noted the importance of being able to seek help from the lecturer when facing problems (Item\#5, M=4.45, 96.6\%). Students found it helpful that they could approach the lecturer for advice when needed (Item\#8, M=4.38). 82.8\% of students agree that consulting with the lecturer helped in the completion of the project (Item\#9, M=4.34). 93.1\% of students feel that support from the lecturer was important towards completing their project (Item\#12, M=4.31).

Student comments to support this (quoted ad verbatim):
"Lecturer gave us some suggestions on how to improve the design...”

"Lecturer give me a lot of idea and advice to complete the project..."

"Lecturer: We discuss about the project and ask if we don't know how to do and consult student..."

\section{CONCLUSION}

In conclusion, web technologies when embedded within a learning environment using a theoretical framework is shown to be able to encourage collaborative problem-solving amongst students. Feedback from the students indicates that they enjoyed the learning environment, were more motivated, and found the knowledge gained to be relevant and useful. Students were able to work together collaboratively and communicate their ideas to each other in this blended learning environment thus providing support for a closer look at using web technologies or Web 2.0 tools to foster collaborative learning.

\section{REFERENCES}

[1] G. Conole, "Designing for learning in an open world," in Explorations in the Learning Sciences, Instructional Systems and Performance Technologies 4, Springer Science+Business Media, LLC 2013.

[2] B. Alexander, "Web 2.0: A new wave of innovation for teaching and learning?" EDUCAUSE Review, vol. 41, no. 2, pp. 32-44, 2006.

[3] M. Prenksy, "Digital natives, digital immigrants," On the Horizon, vol. 9 , no. $5,2001$.

[4] O. S. Tan, C. T. Teo, and S. Chye, "Problems and creativity," in Problem-Based Learning and Creativity, O. S. Tan, Ed., Singapore: Cengage Learning Asia Pte Ltd, 2009, pp. 1-14.

[5] M. D. Merrill, "First principles of instruction," Educational Technology Research and Development, vol. 50, no. 3, pp. 43-59, 2002.

[6] M. M. Lombardi, "Authentic learning for the 21st century: An overview," Educause Learning Initiative, 2007.

[7] MOE, National Education Policy, Ministry of Education, Malaysia, 2012.

[8] PSPTN, Pelan Tindakan Pengajian Tinggi Negara Fasa 2 (2011-2015), Ministry of Higher Education, 2013.

[9] F. C. Lunenburg, "Critical thinking and constructivism techniques for improving student achievement," National Forum of Teacher Education Journal, vol. 21, no. 3, pp. 1-9, 2011.

[10] P. Goodyear, C. Jones, and K. Thompson, "Computer-supported collaborative learning: Instructional approaches, group processes and educational designs," in Handbook of Research on Educational Communications and Technology, J. M. Spector, M. D. Merrill, J. Elen, M. J. Bishop, Eds., New York: Springer, 2014, pp. 439-451.

[11] M. N. K. Boulos, I. Maramba, and S. Wheeler, "Wikis, blogs and podcasts: A new generation of Web-based tools for virtual collaborative clinical practice and education," BMC Medical Education, vol. 6, no. 41, 2006.

[12] P. G. Garcia, "Collaborative learning activities in online courses: issues and strategies," ASEAN Journal of Open Distance Learning, vol. 4, no. $1,2012$.

[13] H. Suh, "Collaborative learning models and support technologies in the future classroom," International Journal for Educational Media and Technology, vol. 5, no. 1, pp. 50-61, 2011.

[14] R. Chiong and J. Jovanovic, "Collaborative learning in online study groups: An evolutionary game theory perspective," Journal of Information Technology Education, vol. 11, pp. 81-101, 2012.

[15] R. Oliver, "When teaching meets learning: Design principles and strategies for web-based learning environments that support knowledge construction," ASCILITE, pp. 17-28, 2000.

[16] G. Mahajan, "Multimedia in teacher education: perceptions \& uses," Journal of Education and Practice, vol. 3, no. 1, pp. 5-12, 2012.

[17] J. Herrington and L. Kervin, "Authentic learning supported by technology: 10 suggestions and cases of integration in classrooms," Educational Media International, vol. 44, no. 3, pp. 219-236, 2007.

[18] J. Herrington, T. Reeves, and R. Oliver, A Guide to Authentic e-Learning, New York: Routledge, 2010. 
[19] C. P. Lim, M. S. Khine, T. Hew, P. Wong, D. Shanti, and B. Lim, "Exploring critical aspects of information technologies integration in Singapore schools," Australian Journal of Educational Technology, vol. 19, no. 1, pp. 1-24, 2003.

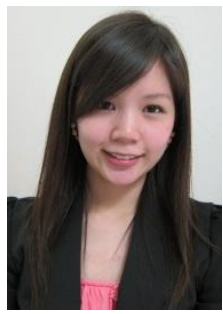

Heidi Tan Yeen-Ju was born in Kuala Lumpur, Malaysia in 1987. She is a lecturer in the Faculty of Creative Multimedia at Multimedia University, Cyberjaya, Selangor, Malaysia. She has recently completed her masters of science in creative multimedia and is currently pursuing a $\mathrm{PhD}$ in the area of problem-solving learning environments and authentic learning strategies.

Ms. Heidi is currently a senior researcher and creative coordinator with the MILE Research Lab under the Centre for Adaptive Multimedia, Education and Learning Content Technologies (CAMELOT). She is a member of the advertising committee within the faculty and she is also a project manager for an external grant project funded by TM R\&D. Her research interests include student centered learning, interactive multimedia applications, authentic learning, multimedia in education, and web-based learning and instruction.

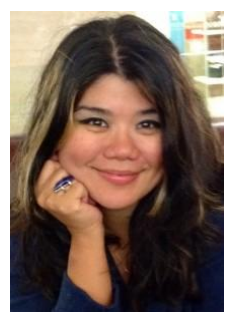

Neo Mai was born in Malaysia in 1968. She is an associate professor and the head of multimedia systems in the Faculty of Creative Multimedia, Multimedia University in Cyberjaya, Selangor, Malaysia. She is also the chair of the Centre for Adaptive Multimedia, Education and Learning Content Technologies (CAMELOT) and a director of the MILE Research Lab, for enhanced student learning in constructivist-based learning platforms. Her previous positions held included Dean, Institute of Postgraduate Studies, Multimedia University, Cyberjaya, Malaysia, Directo of R\&D Collaborations, Multimedia University, and Deputy Dean of Staff and Student Affairs of the Faculty of Creative Multimedia. Currently, she is the program coordinator of the master in multimedia (e-learning technologies) degree in FCM. associate professor Dr. Neo Mai's research interests are in the design of constructivist learning environments and supervises Masters and $\mathrm{PhD}$ students in the following areas: Multimedia authoring technologies in the teaching and learning process, use of interactive multimedia projects in teaching and learning methods, problem-solving learning (PSL), collaborative and cooperative learning, project-based learning, interactive multimedia learning, authentic learning in e-learning environments, using Web 2.0 tools in learning environments. 